\title{
APRESENTAÇÃO.
}

\section{As Comemorações do Sesquicentenário XI de Agosto.}

\author{
Ruy Barbosa Nogueira \\ Diretor da Faculdade de Direito da Universidade de \\ São Paulo. Professor Titular de Direito Tributário \\ na mesma Faculdade
}

No próximo dia 11 de agosto a instituição dos Cursos Jurídicos no Brasil completará 150 anos.

A 11 de agosto do ano passado a Faculdade de Direito do Largo São Francisco procedeu à abertura das comemorações do sesquicentenário, com missa votiva na Igreja de São Francisco, inauguração da remodelação do Largo, da iluminação monumental do edifício e sessão cívico-artística e histórico-cultural que teve a abrilhantá-la poesias, orações, cantos e peças musicais de seus próprios antigos alunos, em coro com os jovens que eternizam as tradições do Largo São Francisco - da velha e sempre nova Academia, onde mora a amizade, onde mora a alegria, onde ao chamar da pátria, se deixa a folha dobrada, enquanto se vai morrer.

Novos livros, reedição de obras históricas, vários cursos de difusão e extensão universitária, congressos, saraus nas Arcadas, concertos sinfônicos, peças teatrais, conferências e tantas outras realizações já se concretizaram ou estão em curso, devendo se encerrar com o congraçamento espiritual, em culto ecumênico na Catedral da Sé; com fraterno almoço dos juristas a 11 de agosto no Anhembi e, à noite, com sessão solene no Salão Nobre da Academia.

Além de novos livros e reedições históricas, estão sendo feitas ainda gravações, fotografias, filmagens e exposições de obras culturais e artísticas. A Faculdade do Largo São Francisco não se esqueceu de obter, como obteve, lei estadual e lei municipal de oficialização dessas comemorações durante um ano, mas ainda, com a devida antecedência, pleiteou e obteve, da Empresa Brásileira de Correios e Telégrafos, a emissão de selo postal comemorativo do SESQUICENTENÁRIO XI DE AGOSTo, 
sugerindo figurar o "fac simile" da Lei que, instituindo os Cursos Jurídicos no Brasil, mandou instalar um curso na cidade de São Paulo e outro em Olinda. No próximo dia 11 de agosto - selo comemorativo estará sendo lançado e carimbado nas Arcadas e no Recife.

Assim também ficará, no universo da filatelia, ressaltado o nascimento concomitante das duas grandes escolas do direito pátrio.

Com efeito.

A Lei de 11 de agosto de 1827 que a Assembléia Geral do Império do Brasil decretou e D. Pedro I, Imperador Constitucional, sancionou, foi referendada pelo então Ministro Visconde de São Leopoldo que, como Deputado Federal (José Feliciano Fernandes Pinheiro), tanto se havia dedicado ao projeto da Fundação dos Cursos Jurídicos no Brasil.

Esta.. Lei representa não só o marco inicial do ensino superior brasileiro, mas sobretudo o despertar da consciência nacional no campo da cultura. Nada mais necessário foi, para solidificar a independência da nova nação, do que iniciar seus próprios filhos no estudo das ciências jurídicas e sociais, para poderem melhor elaborar leis de estruturação do Estado e implantação da nova ordem, em harmonia com a vida e sentimentos da família brasileira.

Criados desde logo no Brasil dois cursos jurídicos, um em São Paulo e outro em Olinda (este depois transferido para o Recife), foram chamados de Academias de Direito, tendo em 1853 a denominação passado para Faculdades de Direito.

Nascidas apenas um lustro depois da independência, estas escolas, quer no Império, quer na República, passaram a atender às aspirações que as criaram, formando os homens públicos para a Nação e os expoentes da intelectualidade brasileira.

Em São Paulo e no Recife formaram-se bacharéis em ciências jurídicas e sociais que vieram a ser incontáveis guias da nacionalidade, a começar pelos Presidentes civis do Brasil, cuja memória devemos reverenciar: PRUdente DE Morais, Campos Salles, Rodrigues Alves, Afonso Pena, Delfim Moreira, Wenceslau Brás, ARThur Bernardes, Washington LUÍs e JOSÉ LINHARES. Juristas de renome internacional como Teixeira de Freitas, Ruy Barbosa, Pimenta Bueno e Clovis BEVILACQUA; diplomatas como o BARÃo Do RIO BRANCO; oradores como JoAquim NabUCo, BRasílio Machado e IbRaIM Nobre; jusfilósofos como Tobias Barreto e Pedro Lessa; es- 
critores como Alencar, Afonso ARinos, Monteiro Lobato e PaUlo SeTúbal; poetas como Álvares de AzEVEdo, VARELA, Castro Alves, Raymundo Corrêa, Vicente de Carvalho e GuIlherme DE Almeida; estadistas como OURo PrETo; historiadores como HOMEM DE MELLO; heróis sertanistas como COUTO DE MAGalHãeS; jornalistas como Justiniano Rocha, RANgel Pestana e JÚlio Mesquita; compositores como Itiberê da Cunha, Cardoso de Menezes e Carlos de Campos; professores como JosÉ BoNIFÁcio, o Moço, e tantos outros.

Caminhando para 11 de agosto de 1977, data em que serão atingidos 150 anos de sua fundação, as Faculdades de Direito da Universidade de São Paulo e do Recife, irmãs gêmeas, não poderiam deixar de comemorar, como vêm comemorando com justificado júbilo, tão significativa data cívica.

Com o jusfilósofo Miguel REale, podemos dizer que essas tradicionais escolas de ensino e culto do Direito e da Justiça, por sua intencionalidade, são tempo e templos da nacionalidade.

Nada melhor, pois, para figurar no selo comemorativo do SESQUiCENTENÁRIo XI DE AGOSTO do que o "fac simile" daquela augusta lei, como símbolo que é, da independência nacional. 